\title{
Public Trust in the European Legal Systems: Independence, Accountability, and Awareness
}

\author{
Nuno Garoupa ${ }^{a} \&$ Pedro C. Magalhães ${ }^{b}$ \\ aAntonin Scalia Law School, George Mason University; ${ }^{b}$ Institute of Social Sciences, \\ University of Lisbon.
}

\begin{abstract}
Two findings stand out in the literature on public attitudes vis-à-vis courts. The first is that judicial independence increases public trust. The second is that 'to know courts is to love them.' In this study, these stylized facts are used as a starting point to ask three questions. First, is there also a role for judicial accountability in fostering public trust, above and beyond that played by independence? Second, could it be that only the most aware citizens are sensitive to such properties of the judicial system? Third, is the notion that 'to know courts is to love them' limited to systems with high levels of judicial independence and accountability? Using recently available macro-level indicators of judicial independence and accountability and the high-quality survey data collected by the European Social Survey in 32 countries throughout more than a decade, this study provides evidence that the answers to these questions are positive.
\end{abstract}

\section{Keywords:}

trust in courts; judicial independence; judicial accountability; awareness

This is an Accepted Manuscript of an article published by Taylor \& Francis in West European Politics on Feb I4 ${ }^{\text {th }} 2020$ available online: https://www.tandfonline.com/eprint/FM5UECKP5WFWPU3 3 JJFY/full?target=I0.IO80/OI 402382.2020.1715605.

CONTACT: Pedro C. Magalhães [pedro.magalhaes@ics.ul.pt] 


\section{Introduction}

As Justice Frankfurter famously noted, in the absence of 'sword' and 'purse', the authority of courts 'ultimately rests on sustained public confidence'. Such confidence is important to courts because they lack direct means of control over the implementation of their decisions or — in most cases — the direct popular legitimization that can arguably be provided by elections. Investment and trade are also more likely to flourish when a trustworthy system of dispute resolution, protection of property rights, and contract enforcement is in place (North I990). And in a age when courts have become the targets of populist leaders and movements that treat them as 'elitist' obstacles to the 'will of the people' (Mudde and Kaltwasser 20I7: II6), their capacity to resist pressures towards increased majoritarianism or even illiberal forms of governance lies precisely on their ability to preserve strong public support (Arato 20I6: 22I).

However, what makes judicial systems trustworthy in the eyes of the public? We answer this question by addressing three interrelated issues. First, one of the central claims in the scarce comparative empirical literature on this topic is that people's trust in legal systems responds to specific 'institutional qualities of the third power' (Bühlmann and Kunz 20II: 3I8), particularly to judicial independence. However, as Ferejohn and Kramer put it, while independence allows judges and courts 'freedom from certain foreseeable pressures to ignore the law (...), it also frees them from any pressure to follow it, and it allows them to make law in ways that could be problematic' (2002: 973). In other words, even if judicial independence matters for trust, to what extent does judicial accountability also matter? 
Second, should all citizens be equally sensitive to the relevant institutional properties of judicial systems? As we discuss in greater detail later, public knowledge about judicial institutions is rather low in most countries on which data are available. Should we expect all citizens' confidence in the legal system to be boosted equally or equivalently by the independence and/or accountability, or should we instead expect only those who are most aware and informed to react positively to such properties? Finally, a third interrelated question concerns the relationship between citizens' legal awareness and their support for judicial systems. Research on support for high courts in the United States and several Western European countries suggests a simple message: 'to know courts is to love them' (Gibson et al. 1998). However, is such regularity a universal truth or is it a function of the fact that it has been mostly investigated in contexts where judicial independence and accountability are comparatively high? What happens to the relationship between awareness and trust when we look at contexts where judiciaries are institutionally dependent and/or unaccountable?

We address these questions by using high-quality survey data collected in 32 European countries through the European Social Survey (ESS) for more than a decade, using a total of I73 surveys of nationally representative samples of national populations, totalling more than 300,000 respondents. These data are coupled with system-level measures of both de facto judicial independence (Linzer and Staton 20I5; Staton et al. 20I9) and judicial accountability (Coppedge et al. 2019; Pemstein et al. 2019). As far as we know, this is vastest array of data ever compiled for a comparative empirical analysis of public attitudes vis-à-vis judicial systems. The study is structured as follows: in the next section, we present 
our theoretical arguments about the importance of judicial independence, judicial accountability, and their interaction with political awareness in the explanation of trust in legal systems. In section three, we present the data employed, our analytical strategy, and our results. Section four concludes.

\section{Independence, Accountability, and Awareness}

\section{Independence}

The concept of 'judicial independence' varies across disciplines and is the object of a vast literature assessing its different understandings (Zemans 1999; Ferejohn 2003; Levinson 2006; Gardner Geyh 20I4). However, at its very core, judicial independence always requires institutions that shelter 'the process of adjudication from interference by the political officials responsible for writing or enforcing law' (Ferejohn and Kramer 2002: 967). By preventing such interference, 'impartiality, fairness, and regularity in the interpretation and application of law' are promoted (Ferejohn and Kramer 2002: 967).

Understandably, courts that are independent also become more trustworthy in the eyes of citizens. As a vast socio-psychological literature has shown, impartiality and neutrality, core elements of procedural fairness in decision-making, increase citizens' trust in and support for all kinds of authorities (Lind and Tyler 1988; Grimes 2006). Comparative research confirms the positive role played by judicial independence. This includes not only comparative studies of U.S. state courts (Benesh 2006) but also several cross-national studies (Bühlmann and Kunz 20II; Salzman and Ramsey 20I3; Çakır and Şekercioğlu 20I6; 
Walker 20I6), showing that in contexts where de facto judicial independence is higher, individuals tend to have greater confidence in the judicial system.

\section{Accountability}

Desirable and trust-inducing as it may be, independence begs the question: 'what do we do about lawless courts and irresponsible judging?' (Ferejohn and Kramer 2002: 973). As Voigt (2008) puts it, although we want judges and courts to be independent, we also want them to be accountable, or to act in way that can be induced by accountability: 'treat the parties appearing in front of them with respect, to separate relevant from irrelevant arguments, and to decide the case within a reasonable period of time according to the letter of the law' (Voigt 2008: 97).

The potential tensions and trade-offs between independence and accountability are a perennial theme in legal and political theory. Although they can be seen as means towards the same end - a judicial process 'in which decisions are made for appropriately legal sorts of reasons, without regard for considerations that law considers extraneous or immaterial' (Ferejohn and Kramer 2002: 974) —, in practice, maximizing both goals is not always easy or even possible. Making use of the principal-agent model, Garoupa and Ginsburg (2015) suggest that there is a potential trade-off between independence and accountability. On the one hand, extreme 'accountability' can hurt 'judicial independence' by subjugating the judiciary to the wishes and wills of guardians, including the electorate (the principal in their model). However, weak 'accountability' can transform 'judicial independence' into pure judicial self-government, failing to disincentivise judicial misconduct, unlawfulness, or inefficiency (thus serving the agent in their model). One clear 
example of this potential trade-off is external judicial auditing, which enhances accountability (beyond mere assessment of backlogs and legal expertise) but opens the possibility for direct interference with the judiciary.

Many qualitative, historical, and institutional studies have provided illustrations of the tension between independence and accountability, as Garoupa and Ginsburg (2015) review. One such illustration is related to the consequences of the creation of judicial councils in some post-authoritarian systems in Europe. These councils are wholly or partially elected by judges among their peers, and put in charge of appointments, discipline, and promotions, with the goal of increasing the 'external' independence of judiciaries (Guarnieri 2004). While awarding those tasks to such collegial bodies can deprive political actors of important means of coercion over judges (thus departing from the authoritarian past), it has also sometimes resulted in 'the capture of the judicial council by the judiciary itself' (Ginsburg and Garoupa 2009: 62). By increasing 'internal' independence vis-à-vis higherranking judges, judicial councils also have, in some cases, subverted the traditional hierarchical orders in many countries (Ginsburg and Garoupa 2009: 76) and, by doing so, 'dismantled the traditional forms of assessment of judicial performance' (Guarnieri 20I3: 353). Cases such as Italy and several Eastern European countries have been used to illustrate this phenomenon, ${ }^{1}$ through which judicial independence without accountability can result, in practice, in a purely self-regulated judiciary, insulated from society, and unresponsive in terms of performance and good practice. 
However, in Garoupa and Ginsburg's (2015) model, the trade-off between accountability and independence is not necessarily universal and general: instead, it varies across time, jurisdictions and, particularly, different dimensions of independence and accountability. The compatibility between independence and accountability is made possible by the fact that both work at multiple dimensions (see also Bermant and Wheeler 1994 and Burbank 1999). Independence can be 'personal/behavioural' (judges are individually free of pressure), 'collective or institutional' (the judiciary as a whole is independent from pressures from other branches of government), 'procedural' (judges can adjust procedure in the courtroom as they see fit in order to assure procedural fairness) or 'administrative' (preventing court budgets, judicial salaries, or promotions from being politically regulated), with procedural and administrative potentially lumped together as 'decisional' independence (Gardner Geyh 20I4). Judicial accountability is also multidimensional, as when, for example, the judiciary as whole is accountable before other branches of government (collective/institutional) or when judges can be made accountable for individual misconduct and wrongdoing (personal/behavioural). This makes it possible, for example, that a high level of personal accountability of judges can virtuously coexist with a high level of institutional independence of the judiciary (Garoupa and Ginsburg 2015).

This is perhaps the main reason why, when examining judicial independence and accountability, empirical studies have found that available indicators of both end up being positively (rather than negatively) correlated (Voigt 2008: 108). Furthermore, several positive outcomes have been shown to result from the maximization of some dimensions of both. Voigt (2008) shows that GDP per capita is positively related with both de facto 
judicial independence and accountability. Voigt and Gutmman (2015) show additional positive effects of accountability: systems where judicial decisions are published and require a higher level of legal justification on the part of judges are associated with lower levels of corruption both in the judiciary and in the public sector as a whole. These findings suggest that, in real world systems, independence and accountability can be intrinsically consistent and understood as virtuous and socially valued goals of the institutions that regulate judicial systems. However, the role of accountability in fostering public support has, as far as we know, never been comparatively examined. We therefore test a second hypothesis: the greater the level of judicial accountability, the more individuals should trust their legal system.

\section{Awareness}

Courts tend to be less visible or salient for people than the kind of elected political institutions whose public support is regularly gauged in public opinion studies. Knowledge of and attention to courts, criminal justice, sentencing, and judicial appointment and retention rules and practices is generally low in most countries on which we have data, including highly developed nations (Roberts and Stalans I998; Bowal and Wanke 200I; Hough and Roberts 1999; Mirrlees-Black 2013). ${ }^{2}$ At the very least, people's awareness 'the extent to which an individual pays attention (...) and understands what he or she has encountered' (Zaller 1992: 2I) — of the institutional properties and operation of judicial systems is likely to vary significantly.

We expect such variations in awareness to interact with judicial independence and accountability in the explanation of trust in the judicial system for two main reasons. First, 
awareness should moderate the relationship between the 'institutional qualities of the third power' - such as independence and accountability — and trust. People who have higher levels of attention and information are likely to be more sensitive than others to their legal system's actual level of independence and accountability when forming an evaluation of that system. This expectation also follows from Garoupa and Ginsburg (2015). Although they do not consider awareness, it inevitably plays a significant role in the context of the principal-agent model. In their model, independence and accountability emerge as mechanisms to regulate the relationship between the principal (the public more generally) and the agent (the judiciary). Hence, the extent to which the principal is aware of the agent matters for institutional arrangements. Unaware principals will remain oblivious to institutional choices, allowing agents to implement their preferred solutions to independence and accountability.

Indeed, there is already some evidence that individuals' response to contextual factors varies according to their level of awareness. For example, 'the harmful effect of high levels of corruption on political trust (and to a lesser extent: the effect of macro-economic performance) is most prevalent among the higher educated' (Van der Meer and Hakhverdian 20I7: 98). Even closer to the point, Wenzel et al. (2003) show that, in the United States, only among most educated citizens are levels of public confidence in state courts affected by judicial selection methods.

Second, the system's institutional properties should themselves moderate the relationship between awareness and trust. One well-known regularity in the study of the relationship 
between citizens' awareness and their attitudes towards courts is that, at least for the U.S. and some European cases, 'those who know more about courts are more likely to support them' (Gibson 2007: 5I6). The main argument is that such awareness also means exposure to messages and symbols that convey a fundamental message: courts are different from ordinary political institutions, and thus 'worthy of more respect, deference, and obedience' (Gibson 2007: 5I6; Gibson et al. 20I4: 840).

However, what happens when awareness means exposure to a different message, one whose content instead conveys the notion that courts and judges lack independence and/or are unaccountable? Several studies have shown that, as we expand the scope of analysis beyond the contexts of the U.S. and Western Europe, awareness appears to be unrelated to trust (Bühlmann and Kunz 20II; Driscoll and Nelson 20I8), or even negatively related to it (Salzman and Ramsay 20I3; Boateng and Adjorlolo 20I9). Even closer to the point, Çakır and Şekercioğlu (20I6) show that the relationship between what they call 'political awareness' and confidence in courts is not uniform across countries, depending on how democratic they are. In other studies of political trust, a similar phenomenon emerges: the positive relationship between one's level of education with trust is only present in contexts of low corruption, and dissipates or even becomes negative when corruption is high (Hakhverdian and Mayne 20I2; Agerberg 20I8). Thus, we expect that, under systems with vigorous judicial independence and accountability, greater awareness should correlate positively with trust in the judiciary, but when those properties are absent, more aware citizens should instead be more likely to distrust their legal system. 
In sum, our discussion of the relationship between independence, accountability, awareness, and trust in the legal system suggests four main hypotheses:

HI: The greater the level of de facto judicial independence, the more individuals should trust their legal system.

$\mathrm{H} 2$ : The greater the level of judicial accountability, the more individuals should trust their legal system.

$\mathrm{H}_{3}$ : The relationships between independence and accountability and trust in the legal system should be stronger for individuals with greater levels of political awareness.

$\mathrm{H}_{4}$ : The relationship between awareness and trust in the legal system should be positive when levels of independence and accountability are high, but negative when levels of independence and accountability are low.

\section{Data, analysis, and results}

\section{Individual-level data}

To capture individuals' Trust in the legal system, we resort to the European Social Survey (ESS). Each respondent, in each wave of the ESS in every country, has been asked to rate the level of trust she deposits in her country's legal system, on a scale of o ('No trust at all') to Io ('A lot of trust'). We used the data of the ESS rounds I to 7, a vast pooled cumulative dataset from all countries that have been included in the integrated ESS files in two or more rounds (ESS 20I6). Overall, this dataset contains 331,87I individual-level observations, resulting from a total of 173 surveys of nationally representative samples of populations with I5 years of age or more, conducted in 32 European countries during I4 years. 322,20I respondents provided valid answers to the question about trust in the legal system. ${ }^{3}$ 
The nature of 'trust' or 'confidence' when applied to the study of support for courts has been exhaustively examined in the American literature. 'Trust' is conceptually and empirically distinct from 'legitimacy' or 'diffuse support,' reflecting instead a 'holistic judgment about institutional performance' (Gibson et al. 2003: 36I). Such judgments about the judicial system seem to be strongly driven by more general attitudes towards governmental institutions (Stoutenborough and Haider-Markel 2008; Hansen 20I7; Ansolabehere and White forthcoming). In order to isolate the empirical relationship between the institutional properties of the judicial system and people's trust in it from other processes that might be driving support for governmental institutions as a whole, we follow Bühlmann and Kunz (20II) and control for Trust in parliament, also measured on a o to IO scale in all ESS rounds. This is a particularly stringent control, given that questions employed to measure trust in different objects (including the legal system and parliament) in the ESS are always posed in a block of immediately adjacent items, causing responses to each item to be affected by the proximity of the remaining ones in a way that favours inter-item correlation (Weijters et al. 2009).

Measuring awareness poses a different challenge. Ideally, following Zaller (1992), one would be able to resort to measures about respondents' factual knowledge of the way their judicial system works, particularly, in our case, of institutions and practices that directly impinge on judicial independence and accountability (like in, for example, Gibson and Caldeira 2009). However, such measures are unavailable in the ESS, as in other large-scale cross-national surveys. Thus, we rely on commonly used proxies that are available in all waves of the ESS. One of them is Education, which is measured as the respondents' number 
of years of full-time education (top-coded at 25 years). The other is News media exposure, the responses to a question about the average number of hours spent watching news on politics and current affairs on TV, in an ordinal 8-point scale ranging from 'No time at all' (o) to 'More than 3 hours' (7). ${ }^{4}$

To be sure, although formal education is necessary to acquire the cognitive skills required to develop a greater awareness of the legal system, it is not a sufficient pre-condition, as it does not guarantee the required motivation to seek such information (Zaller I992: 334). Furthermore, we know that formal education is also positively correlated with the espousal of attitudes and values that emphasize liberal dimensions of democracy (Welzel 20II), including, presumably, judicial independence. Conversely, media exposure to news, although a pre-condition to the acquisition of knowledge about political and legal institutions, is also too rough a measure: it fails to distinguish between exposure to different types of media outlets and relies on self-reported exposure and the associated biases (but see Linos and Twist 2016 for how measures of "knowledge" can also be biased by prior beliefs). In any case, we will return to some of the implications of the use of these proxies when discussing the empirical results.

Individual-level control variables include Female (a dummy variable), the Age of the respondent (in years), and Interpersonal trust (the regression-based factor scores based on the three relevant variables in the ESS), variables that other studies have found to be a correlates of institutional trust (see, for example, Keele 2007 or Zmerli and Newton 2008). 


\section{Macro-level data}

Our two main macro-level independent variables are measured for each country and every year in which the EES surveys were conducted. To capture judicial independence, we borrow from the results of a dynamic bounded graded item response theory model developed by Linzer and Staton (2015), which generates a cross-national measure of latent de facto judicial independence (Latent Judicial Independence - LJI), incorporating data from eight manifest variables directly or indirectly capturing de facto judicial independence. ${ }^{5}$ Besides overcoming problems of missing data on one or another indicator for several countries or years, $L J I$ has the major advantage of minimizing measurement error, avoiding both excessive and insufficient sensitivity to contextual changes. Values of $L J I$ range from o to I, from very low to very high de facto judicial independence, and are available for a maximum of I7I countries from 1948 until 2015 (Staton et al. 20I9). The higher the value, the more judges in a given context can expect to be able to decide autonomously and expect such decisions to be implemented without interference (Linzer and Staton 2015: 225).

Judicial Accountability (JA) is obtained from the V-Dem (Varieties of Democracy) dataset (Coppedge et al. 2019; Pemstein et al. 2019). It results from ratings of country experts in response to the following question: 'when judges are found responsible for serious misconduct, how often are they removed from their posts or otherwise disciplined?,' using an ordinal scale of o ('never') to 4 ('always'), converted to a roughly normalized interval scale by the measurement model. In other words, the higher the value, the more judges are 
held personally responsible for misconduct in a given system, pointing, as discussed earlier, to a dimension of personal/behavioural judicial accountability.

In our sample of cases - I73 country-years - LJI ranges from .325 to .99I, with an average of .85I and a standard deviation of .I67. $J A$ ranges from -I.539 to 3.634, with an average of I.72 and a standard deviation of I.I3. Importantly, the two variables are highly correlated in our sample of ESS countries, at .80. This has two implications. On the one hand, it confirms the compatibility of independence and accountability in real world systems and across countries, at least when measured in their respective institutional (independence) and personal/behavioural (accountability) dimensions. On the other hand, high correlation between these measures will tend to increase the variance of the estimates of their parameters when regressing trust on them, decreasing precision in the estimation of the partial effects of independence and accountability, and thus the likelihood that null hypotheses about them can be rejected (Kennedy 2008: 193-194). Nevertheless, we will assess the implications of this correlation between our two main variables by examining the sensitivity of the estimates to their joint presence in the models and the presence and absence of other predictors. Furthermore, one should recall that, if we are still able to reject null hypotheses about the effects of either independence or accountability in the presence of a high correlation between the two variables, this supports - rather than detracts from — their relevance as independent predictors.

Bühlmann and Kunz (20II) also found that confidence in the judicial system tends to be higher for people living in countries with larger populations and greater GDP per capita, 
with opposite results for contexts where common law systems prevail (20II: 329). Thus, as controls, we add Population (the log of population in millions), GDP per capita (logged) and a dummy for UK common law legal origins (taken from La Porta et al. 2008). Furthermore, in one of the specifications, we employ country- and survey year-fixed effects.

\section{Analysis and results}

We start by presenting simple bivariate patterns of the relationship between Latent Judicial Independence and Judicial Accountability, on the one hand, and Trust in the legal system, on the other. Figure I shows two scatterplots: on the left, the sample averages of Trust in the legal system in all ESS surveys are plotted against the respective country-year values of $L J I$ for all our observations; on the right, the same, but in this case against country-year values of Judicial Accountability. Clearly, in countries where judicial independence and judicial accountability are higher, trust in the legal system also tends to be higher.
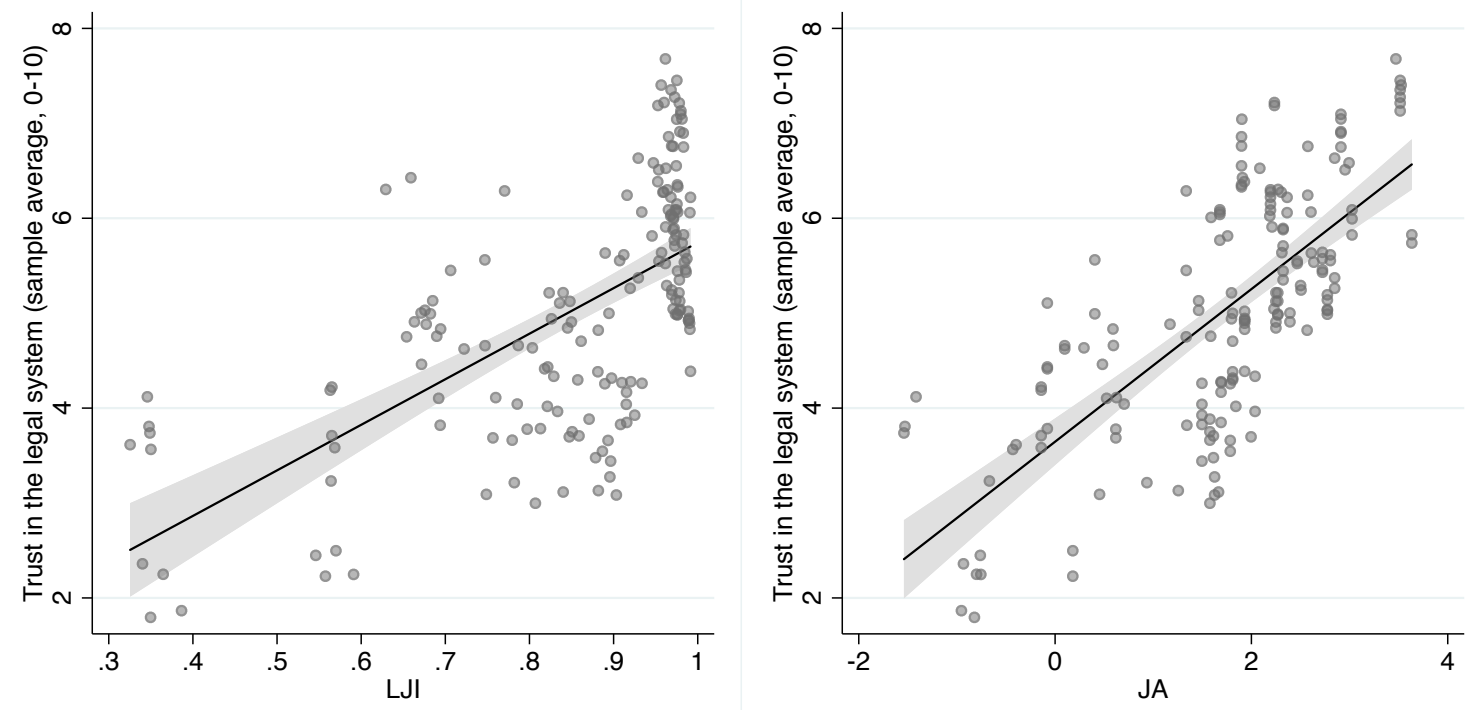

Figure I. Latent Judicial Independence and Judicial Accountability (horizontal axes) and Trust in the legal system (vertical axis). ESSI-7, aggregate level data. 
In order to take our analysis further, employing multivariate analyses combining individual- and macro-level observations, we need to consider that our data is composed by measurements of survey respondents in different countries and different years. In order to take into account the nested nature of the data, we employ multilevel models. In this case, individuals are nested in two higher-level contexts — country and survey year — but these two contexts are not nested among themselves. Instead, respondents are nested within the cells of a cross-classification of countries by years. Thus, we estimate cross-classified multilevel linear regression models, which specify between-country and between-survey year variances and estimate variance at the year level while assuming that variance is equal across countries and vice versa (Rabe-Hesketh and Skrondal 20I2: 433-44I).

To test $\mathrm{HI}$ and $\mathrm{H} 2$, we regress trust on LJI and JA, entering them separately (models I and 2) and jointly (model 3), first with macro-level controls, and then with both macro- and micro-level controls (models 4 to 6). Table I shows the results. 
Table I. Judicial independence (LJI) and judicial accountability (JA) as correlates of trust in legal systems: multilevel cross-classified random intercept model.

\begin{tabular}{|c|c|c|c|c|c|c|c|c|c|c|c|c|}
\hline & \multicolumn{2}{|c|}{ Model I } & \multicolumn{2}{|c|}{ Model 2} & \multicolumn{2}{|c|}{ Model 3} & \multicolumn{2}{|c|}{ Model 4} & \multicolumn{2}{|c|}{ Model 5} & \multicolumn{2}{|c|}{ Model 6} \\
\hline & $\begin{array}{l}\text { Coef } \\
(\mathrm{SE})\end{array}$ & p-value & $\begin{array}{l}\text { Coef } \\
\text { (SE) } \\
\end{array}$ & p-value & $\begin{array}{l}\text { Coef } \\
\text { (SE) }\end{array}$ & p-value & $\begin{array}{l}\text { Coef } \\
(\mathrm{SE}) \\
\end{array}$ & p-value & $\begin{array}{l}\text { Coef } \\
(\mathrm{SE}) \\
\end{array}$ & p-value & $\begin{array}{l}\text { Coef } \\
(\mathrm{SE})\end{array}$ & p-value \\
\hline LJI & $\begin{array}{c}3 . \mathrm{I} 6 * * * \\
(.26)\end{array}$ & .000 & - & - & $\begin{array}{c}3 \cdot 3 \mathrm{I}^{* * *} \\
(.26)\end{array}$ & .000 & $\begin{array}{c}\mathrm{I} .85^{* * *} \\
(.2 \mathrm{I})\end{array}$ & .000 & - & - & $\begin{array}{c}\mathrm{I} .88 * * * \\
(.2 \mathrm{I})\end{array}$ & .000 \\
\hline JA & - & - & $\begin{array}{c}.28 * * * \\
(.02)\end{array}$ & .000 & $\begin{array}{c}.29 * * * \\
(.02)\end{array}$ & .000 & - & - & $\begin{array}{l}.05^{* *} \\
(.0 \mathrm{I})\end{array}$ &. $\mathrm{OOI}$ & $\begin{array}{c}.05^{* * *} \\
(.0 \mathrm{I})\end{array}$ & .000 \\
\hline Population (log) & $\begin{array}{l}.22 * \\
(.09)\end{array}$ & .018 & $\begin{array}{l}.15^{+} \\
(.08)\end{array}$ & .086 & $\begin{array}{l}.24^{* *} \\
(.09)\end{array}$ & .007 & $\begin{array}{c}.04 \\
(.06)\end{array}$ & $.5 \mathrm{II}$ & $\begin{array}{l}.003 \\
(.07)\end{array}$ & .965 & $\begin{array}{c}.04 \\
(.06)\end{array}$ & .472 \\
\hline GDP per capita (log) & $\begin{array}{c}.98^{* * * *} \\
\text { (.Io) }\end{array}$ & .000 & $\begin{array}{c}\text { I.I } 8 * * * \\
(.09)\end{array}$ & .000 & $\begin{array}{c}.72 * * * \\
\text { (.Io) }\end{array}$ & .000 & $\begin{array}{c}-.37^{* * *} \\
(.08)\end{array}$ & .000 & $\begin{array}{l}-.16^{*} \\
(.07)\end{array}$ & .029 & $\begin{array}{c}-.42^{* * *} \\
(.08)\end{array}$ & .000 \\
\hline Common law legal origin & $\begin{array}{c}.04 \\
(.46)\end{array}$ & .928 & $\begin{array}{c}.07 \\
(.4 \mathrm{I})\end{array}$ & $.86 \mathrm{I}$ & $\begin{array}{l}-.24 \\
(.45)\end{array}$ & .592 & $\begin{array}{c}.33 \\
(.3 \mathrm{I})\end{array}$ & .276 & $\begin{array}{c}.47 \\
(.32)\end{array}$ & .148 & $\begin{array}{c}.28 \\
(.30)\end{array}$ & .349 \\
\hline Female & - & - & - & - & - & - & $\begin{array}{l}.02^{*} \\
(. \mathrm{OI})\end{array}$ & .014 & $\begin{array}{l}.02 * \\
(. \mathrm{OI})\end{array}$ & $.0 \mathrm{I} 4$ & $\begin{array}{l}.02^{*} \\
(. \mathrm{OI})\end{array}$ & .014 \\
\hline Age & - & - & - & - & - & - & $\begin{array}{c}-.004^{* * *} \\
(.0002)\end{array}$ & .000 & $\begin{array}{c}-.004^{* * *} \\
(.0002)\end{array}$ & .000 & $\begin{array}{c}-.004^{* * *} \\
(.0002)\end{array}$ & .000 \\
\hline Trust in parliament & - & - & - & - & - & - & $\begin{array}{l}.57^{* * *} \\
(.002)\end{array}$ & .000 & $\begin{array}{l}.57^{* * *} \\
(.002)\end{array}$ & .000 & $\begin{array}{l}.57^{* * *} \\
(.002)\end{array}$ & .000 \\
\hline Interpersonal trust & - & - & - & - & - & - & $\begin{array}{l}.37^{* * *} \\
(.005) \\
\end{array}$ & .000 & $\begin{array}{l}.37^{* * *} \\
(.005) \\
\end{array}$ & .000 & $\begin{array}{l}\cdot 37^{* * * *} \\
(.005) \\
\end{array}$ & .000 \\
\hline N observations & \multicolumn{2}{|c|}{$322,2 \mathrm{OI}$} & \multicolumn{2}{|c|}{$322,20 \mathrm{I}$} & \multicolumn{2}{|c|}{$322,20 \mathrm{I}$} & \multicolumn{2}{|c|}{$3 \mathrm{II}, 457$} & \multicolumn{2}{|c|}{$3 \mathrm{II}, 457$} & \multicolumn{2}{|c|}{$3 \mathrm{II}, 457$} \\
\hline $\mathrm{N}$ countries & \multicolumn{2}{|c|}{32} & \multicolumn{2}{|c|}{32} & \multicolumn{2}{|c|}{32} & \multicolumn{2}{|c|}{32} & \multicolumn{2}{|c|}{32} & \multicolumn{2}{|c|}{32} \\
\hline $\mathrm{N}$ country-years & \multicolumn{2}{|c|}{$\mathrm{I} 73$} & \multicolumn{2}{|c|}{$\mathrm{I} 73$} & \multicolumn{2}{|c|}{$\mathrm{I} 73$} & \multicolumn{2}{|c|}{$\mathrm{I} 73$} & \multicolumn{2}{|c|}{$\mathrm{I} 73$} & \multicolumn{2}{|c|}{$\mathrm{I} 73$} \\
\hline \multicolumn{13}{|l|}{ Variance components } \\
\hline Country & \multicolumn{2}{|c|}{.73} & \multicolumn{2}{|c|}{.59} & \multicolumn{2}{|c|}{.69} & \multicolumn{2}{|c|}{32} & \multicolumn{2}{|c|}{.36} & \multicolumn{2}{|c|}{$\cdot 3 \mathrm{I}$} \\
\hline Year & \multicolumn{2}{|c|}{.03} & \multicolumn{2}{|c|}{.04} & \multicolumn{2}{|c|}{.04} &.$c$ & & & & & \\
\hline Individuals & & & & & & & 3. & & & & & \\
\hline
\end{tabular}

Notes. Intercept not shown, standard errors in parentheses. $+\mathrm{p}<0 . \mathrm{I} ;{ }^{*} \mathrm{p}<0.05 ; * * \mathrm{p}<0.0 \mathrm{I} ;{ }^{*} * \mathrm{p}<0.00 \mathrm{I}$. 
First, people living under judicial systems where independence and accountability are higher tend to lend greater trust to their legal system. The coefficients of LJI and JA are unaffected by their joint or separate inclusion in the models, and are always significant at least at $\mathrm{p}=.00 \mathrm{I}$, regardless of model specification. This supports $\mathrm{HI}$ and $\mathrm{H} 2$.

Second, the coefficients experience sizeable drops in size when individual-level controls are included. In models 4 to 6 , the most powerful predictor of trust in the legal system is Trust in parliament: a one standard deviation increase in the latter is estimated to result in an increase of more than half a standard deviation in Trust in the legal system. This suggests that both judicial independence and judicial accountability are likely to be a part of a broader institutional configuration of domestic institutions - what Voigt calls 'institutional quality' at large (Voigt 2008: 109) — that foster political trust in general. Consequently, once trust in parliament is introduced as a control, the specific institutional properties of the judicial system emerge with a smaller independent relationship with public trust in the legal system. However, considering the above mentioned conservativeness in the estimates that results from introducing Trust in parliament, the fact that those properties of the judicial system remain significant correlates of Trust in the legal system is encouraging.

Finally, judicial independence is a much stronger correlate of trust in the legal system than judicial accountability, in all specifications. Before individual-level controls are introduced (Model 3), a one standard deviation increase in LJI is estimated to increase Trust in the legal system by .55 , about $\mathrm{I} / 5$ of a standard deviation in the dependent, while the equivalent 
change in $J A$ is estimated to increase trust by .33 . In Model 6, these effects drop, respectively, to .3I and .06. While the former is equivalent, for example, to the relationship between Interpersonal trust and Trust in the legal system, the latter is much smaller. In other words, citizens' trust in the legal system seems to be more sensitive to the presence of institutions that guarantee de facto independence of courts than to those that foster personal accountability of judges for misconduct.

However, these are main effects, and we still need to consider $\mathrm{H}_{3}$ and $\mathrm{H}_{4}$. $\mathrm{H}_{3}$ proposed that the effects of independence and accountability should be contingent upon citizens' awareness, while the latter proposed that the effects of awareness should be contingent upon independence and accountability. Table 2 includes results for two types of multilevel cross-classified models. The first introduces cross-level interactions between two of our upper-level variables $(L J I$ and $J A)$ and, in alternation, our two proxies for awareness: Years of education and News media exposure. Following best practice, to minimize overrejection of the null hypothesis of no cross-interaction effect, we adopt the conservative approach of including random slopes for our measures of awareness, the lower-level component of those cross-level interactions (Heisig and Schaeffer 2019). The second type of model, preserving random-slopes for awareness, corrects for the non-independence of observations within countries and years by adding fixed effects for countries and survey years, taking advantage of the fact that our total number of country-year observations of $L J I$ and $J A$ is larger than the number of fixed effects in the model (see Paskov et al. 2017 for a similar approach). 
Table 2. Cross-level interactions between independence, accountability and awareness: random slope models (7 and 8) and random slope models with country and survey-year fixed effects (9 and Io).

\begin{tabular}{|c|c|c|c|c|c|c|c|c|}
\hline & \multicolumn{4}{|c|}{ Random slope models } & \multicolumn{4}{|c|}{ Random slope and country and survey year fixed effects models } \\
\hline & \multicolumn{2}{|c|}{ Model 7: years of education } & \multicolumn{2}{|c|}{ Model 8: news exposure } & \multicolumn{2}{|c|}{ Model 9: years of education } & \multicolumn{2}{|c|}{ Model Io: news exposure } \\
\hline & Coef (SE) & p-value & Coef (SE) & p-value & Coef (SE) & p-value & Coef (SE) & p-value \\
\hline LJI & $\begin{array}{c}\text { I.05** } \\
(.33)\end{array}$ & $.00 \mathrm{I}$ & $\begin{array}{c}\text { I. } 89^{* * *} \\
(.24)\end{array}$ & .000 & $\begin{array}{c}.08 \\
(\mathrm{I} .00)\end{array}$ & .935 & $\begin{array}{l}\text { I.26 } \\
(.79)\end{array}$ &. $\mathrm{IIO}$ \\
\hline JA & $\begin{array}{l}.07^{+} \\
(.04)\end{array}$ & .088 & $\begin{array}{l}.02 \\
(.02)\end{array}$ & .274 & $\begin{array}{l}.06 \\
(.08)\end{array}$ & .433 & $\begin{array}{l}.05 \\
(.06)\end{array}$ & .403 \\
\hline LJI*Awareness & $\begin{array}{l}.06 * * \\
(.02)\end{array}$ & .009 & $\begin{array}{l}-.04 \\
(.07)\end{array}$ & .498 & $\begin{array}{c}.10^{* * * *} \\
(.02)\end{array}$ & .000 & $\begin{array}{l}-.06 \\
(.06)\end{array}$ & $.30 \mathrm{I}$ \\
\hline $\mathrm{JA} *$ Awareness & $\begin{array}{l}-.001 \\
(.002)\end{array}$ & .734 & $\begin{array}{l}.02+ \\
(.01)\end{array}$ & $.06 \mathrm{I}$ & $\begin{array}{l}-.002 \\
(.002)\end{array}$ & .330 & $\begin{array}{l}.02 * * \\
(.01)\end{array}$ & .007 \\
\hline Population (log) & $\begin{array}{c}.05 \\
(.07)\end{array}$ & .449 & $\begin{array}{c}.06 \\
(.06)\end{array}$ & .282 & - & - & - & - \\
\hline GDP per capita (log) & $\begin{array}{c}-.40^{* * *} \\
(.08)\end{array}$ & .000 & $\begin{array}{c}-.40^{* * *} \\
(.08)\end{array}$ & .000 & - & - & - & - \\
\hline UK legal origin & $\begin{array}{l}.32 \\
(.33)\end{array}$ & .327 & $\begin{array}{c}.18 \\
(.29)\end{array}$ & $.53 \mathrm{I}$ & - & - & - & - \\
\hline Female & $\begin{array}{l}.02 * \\
(. \mathrm{OI})\end{array}$ & .020 & $\begin{array}{l}.0 \mathrm{I}^{*} \\
(. \mathrm{OI})\end{array}$ & .036 & $\begin{array}{l}.02 * \\
(.0 \mathrm{I})\end{array}$ & $.02 \mathrm{I}$ & $\begin{array}{l}.0 \mathrm{I}^{*} \\
(. \mathrm{OI})\end{array}$ & .045 \\
\hline Age & $\begin{array}{c}-.004^{* * *} \\
(.0002)\end{array}$ & .000 & $\begin{array}{c}-.004^{* * * *} \\
(.0002)\end{array}$ & .000 & $\begin{array}{c}-.004^{* * *} \\
(.0002)\end{array}$ & .000 & $\begin{array}{c}-.004^{* * * *} \\
(.0002)\end{array}$ & .000 \\
\hline Trust in parliament & $\begin{array}{l}.57^{* * * *} \\
(.001)\end{array}$ & .000 & $\begin{array}{l}.57^{* * * *} \\
(.001)\end{array}$ & .000 & $\begin{array}{l}.56^{* * * *} \\
(.001)\end{array}$ & .000 & $\begin{array}{l}.57^{* * * *} \\
(.002)\end{array}$ & .000 \\
\hline Interpersonal trust & $\begin{array}{l}.37^{* * * *} \\
(.005)\end{array}$ & .000 & $\begin{array}{l}.37^{* * * *} \\
(.005)\end{array}$ & .000 & $\begin{array}{l}.38^{* * *} \\
(.005)\end{array}$ & .000 & $\begin{array}{l}.38 * * * \\
(.005)\end{array}$ & .000 \\
\hline Awareness & $\begin{array}{l}-.04^{*} \\
(.02) \\
\end{array}$ & .014 & $\begin{array}{c}.01 \\
(.05) \\
\end{array}$ & .916 & $\begin{array}{c}-.07^{* * *} \\
(.0 \mathrm{O}) \\
\end{array}$ & .000 & $\begin{array}{r}-.004 \\
(.04) \\
\end{array}$ & .923 \\
\hline $\mathrm{N}$ observations & \multicolumn{2}{|c|}{$3 \mathrm{II}, 457$} & \multicolumn{2}{|c|}{$3 \mathrm{IO}, 46 \mathrm{I}$} & \multicolumn{2}{|c|}{$3 \mathrm{II}, 457$} & \multicolumn{2}{|c|}{$3 \mathrm{IO}, 46 \mathrm{I}$} \\
\hline $\mathrm{N}$ countries & \multicolumn{2}{|c|}{32} & \multicolumn{2}{|c|}{32} & \multicolumn{2}{|c|}{32} & \multicolumn{2}{|c|}{32} \\
\hline $\mathrm{N}$ country-years & \multicolumn{2}{|c|}{$\mathrm{I} 73$} & \multicolumn{2}{|c|}{ I73 } & \multicolumn{2}{|c|}{ I73 } & \multicolumn{2}{|c|}{ I73 } \\
\hline \multicolumn{9}{|l|}{ Variance components } \\
\hline Country & \multicolumn{2}{|c|}{.36} & \multicolumn{2}{|c|}{.28} & \multicolumn{2}{|c|}{-} & \multicolumn{2}{|c|}{-} \\
\hline Year & \multicolumn{2}{|c|}{. $\mathrm{OI}$} & \multicolumn{2}{|c|}{. $\mathrm{OI}$} & \multicolumn{2}{|c|}{-} & \multicolumn{2}{|c|}{ - } \\
\hline Country-year & \multicolumn{2}{|c|}{-} & \multicolumn{2}{|c|}{-} & \multicolumn{2}{|c|}{.03} & \multicolumn{2}{|c|}{.03} \\
\hline Individuals & \multirow{2}{*}{\multicolumn{2}{|c|}{3.73}} & \multirow{2}{*}{\multicolumn{2}{|c|}{3.74}} & & & & \\
\hline Awareness & & & & & & & & \\
\hline
\end{tabular}


First, of the eight cross-level interaction coefficients estimated, only three are statistically significant at $\mathrm{p}<$.0I, and four if we relax to $\mathrm{p}<$.IO. Two (in models 7 and 9 ) pertain to Judicial independence*Years of full-time education, and the other two (in models 8 and Io) to Judicial accountability*News media exposure. In other words, judicial independence and judicial accountability do show significant interactions with Awareness, although through different proxies.

In Figure 2, we present marginal effects plots for Judicial Independence and Judicial Accountability, showing how the estimated effect of both varies with, respectively, Years of full-time education and News media exposure. Furthermore, following Berry, Golder, and Milton (2012), given that we had also hypothesized that the effects of Awareness on trust should be contingent upon the institutional properties of the judicial system, in Figure 3 we present marginal effects plots for Years of full-time education and News media exposure, showing how their effects vary with, respectively, Judicial Independence and Judicial Accountability.

On the left side of Figure 2, we look at the marginal effects of judicial independence conditional on years of education (random slope model above, random slope with fixed effects below), while, on the right, at the marginal effects of judicial accountability conditional on news media exposure (random slope models above, random slope with fixed effects models below). ${ }^{6}$ 


\section{Model 7}

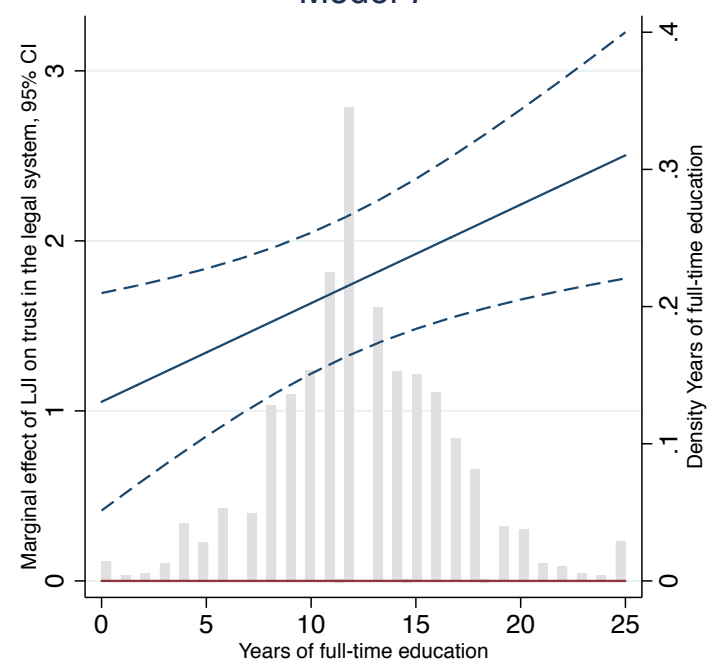

Model 9

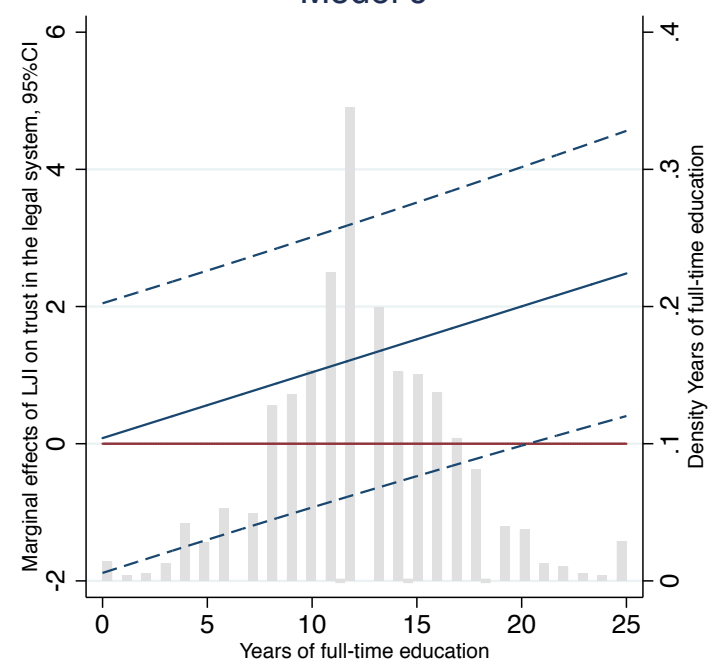

Model 8

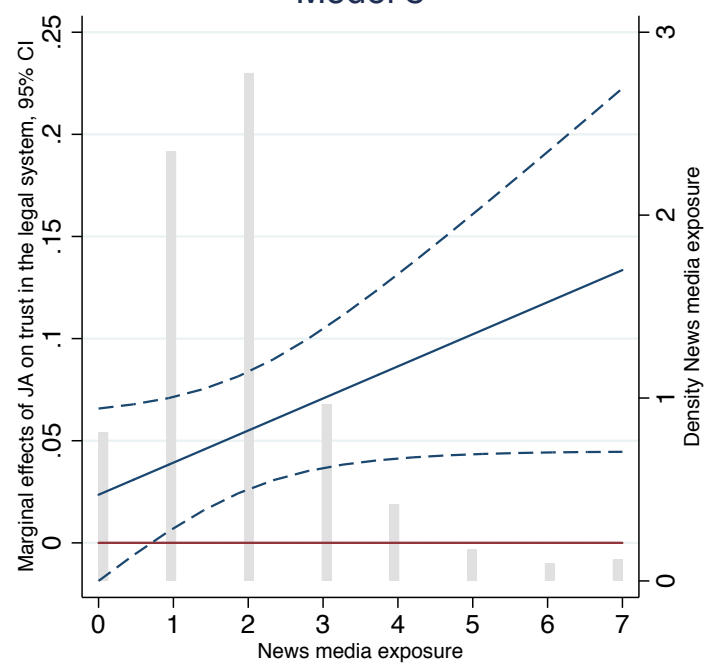

Model 10

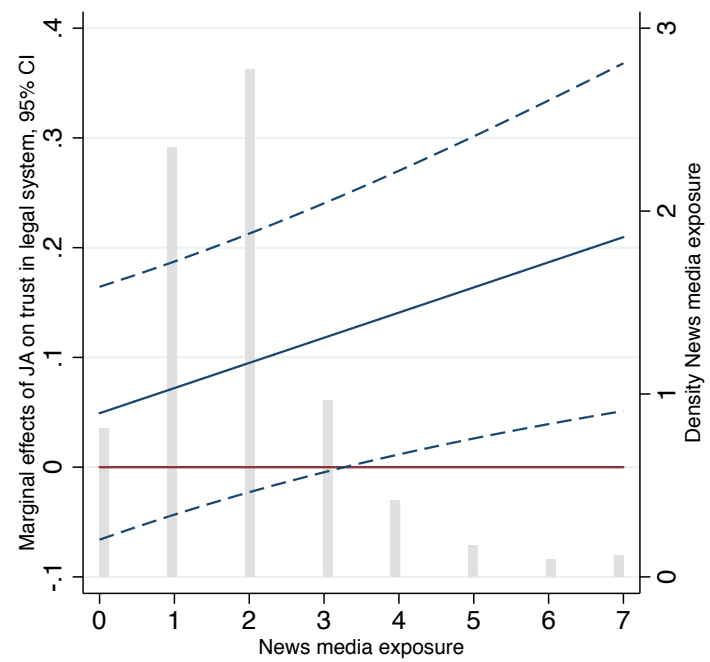

Figure 2. The marginal effects of Latent Judicial Independence and Judicial Accountability on Trust in the legal system, conditional on, respectively, education and news media exposure.

The respondents' level of education moderates the relationship between judicial independence and their trust in the judicial system: the higher the number of years of fulltime of education of the respondent, the stronger the (positive) effect of independence. In model 7, the effect of $L J I$ is positive and increases with education. In Model 9, the effect of $L J I$ is compatible with zero for most of the respondents, but is positive for those with 
greater exposure to the educational system. However, we must recall that, in the case of Model 9, we are introducing country and survey-years fixed effects, which dampens the effect of any slow moving institutional variable, as $L J I$ clearly is among our countries.

Conversely, on the right, the relationship between judicial accountability and people's trust in the judicial system emerges as contingent upon the respondents' exposure to news in the media. At the lowest levels of exposure, the results are compatible with judicial accountability having no relationship with trust in the legal system. However, as exposure increases, the relationship becomes positive (albeit much smaller than the relationship between independence and trust for the highly educated). In general, therefore, the results seem broadly supportive of $\mathrm{H}_{3}$. 
Model 7

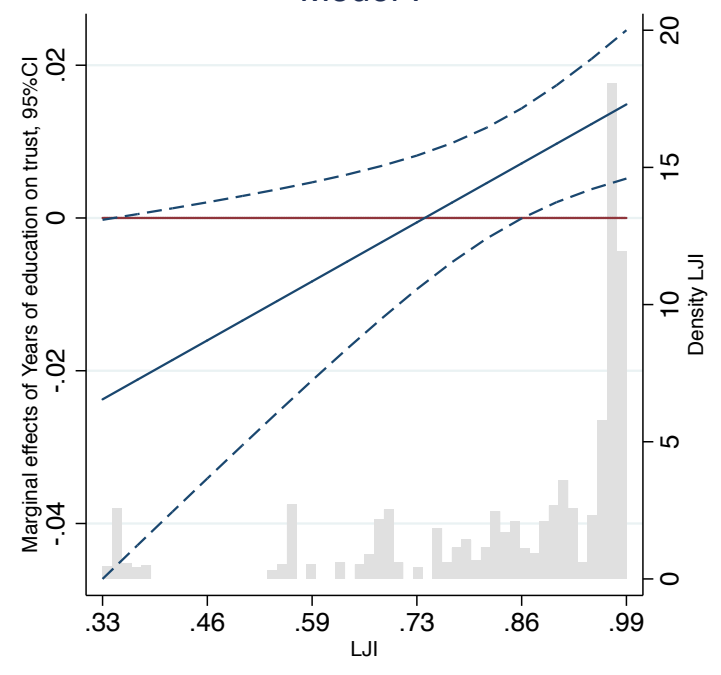

Model 9

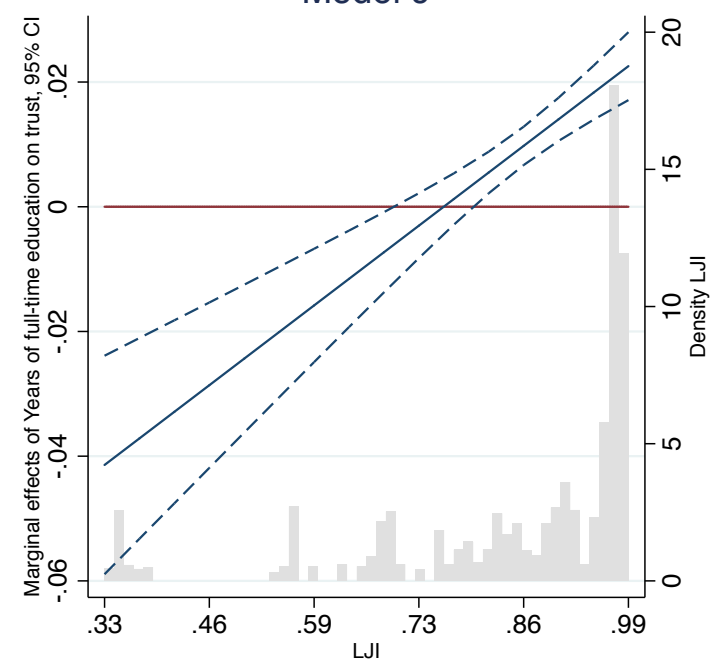

Model 8

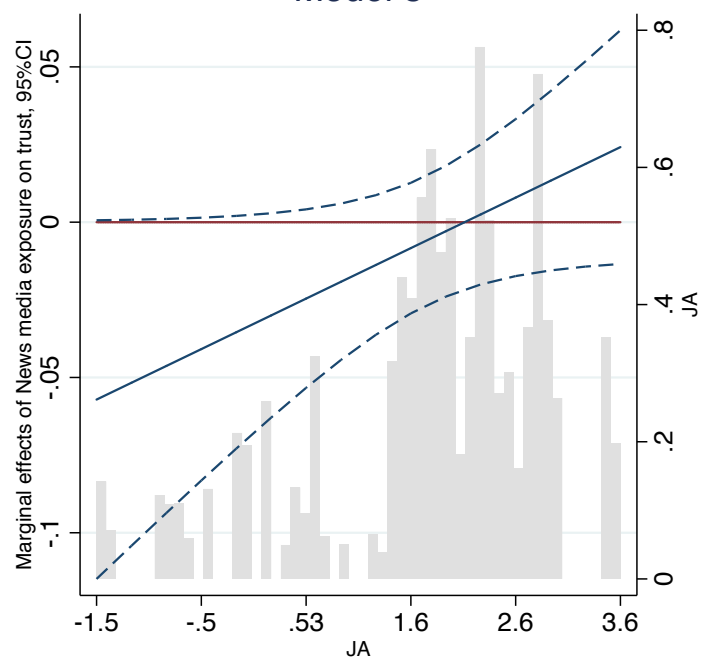

Model 10

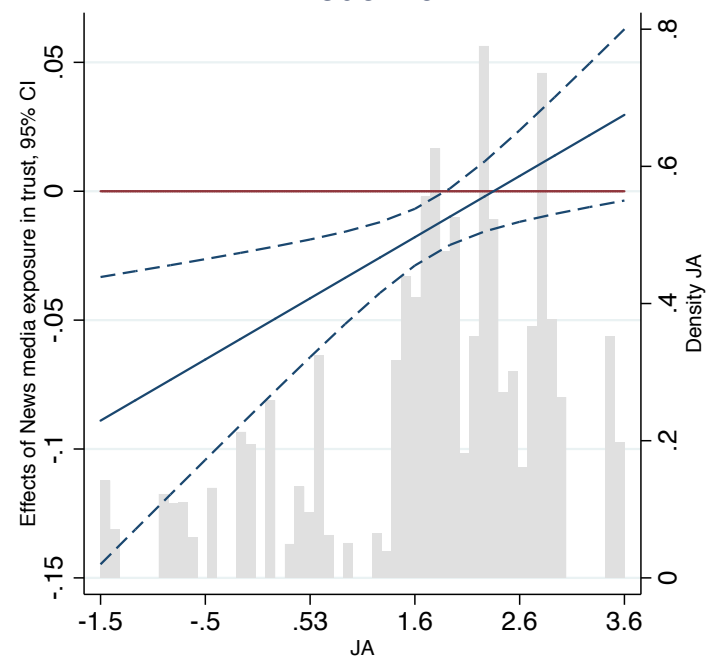

Figure 3. The marginal effects of Years of full-time education and News media exposure on Trust in the legal system, conditional on, respectively, judicial independence and judicial accountability.

In Figure 3, we switch our focus to the extent to which the relationship between awareness and trust is moderated by judicial independence and accountability. On the left side, we can see that, as we move from cases with low de facto independence (in our sample of cases, countries like Ukraine or Russia) to high levels (in countries like Denmark, Switzerland, Norway, or the United Kingdom), the relationship between education and 
trust indeed switches from negative to positive. Although the estimates of the random slope model (Model 7) are less precise than those resulting from the random slope/country and survey years fixed effects model (Model 9), the pattern is the same.

Evidence supporting $\mathrm{H}_{4}$ is slimmer in what concerns the way judicial accountability modifies the effects of news media exposure. On the basis of Model 9, that relationship is negative in contexts of low judicial accountability (such as Russia, Ukraine, Bulgaria, Hungary, or Italy), and compatible with zero (rather than positive) at the highest levels of JA (in countries like Austria, Germany, or Denmark). But on the basis of Model 8, it is unclear whether awareness captured by the 'media exposure' proxy has any relationship with trust in the legal system. Overall, there is weaker support for $\mathrm{H}_{4}$, at least in what concerns judicial accountability. ${ }^{7}$

\section{Conclusion}

Using a vast array of data on trust in the legal system, judicial independence, and judicial accountability in more than 30 European countries over more than a decade, we found that, above and beyond support for governmental institutions in general, people's trust in their judicial systems is positively related with fundamental institutional properties of those systems: judicial independence and judicial accountability. Furthermore, those properties matter most for particular profiles of respondents. Those who are more educated are also more sensitive in their evaluations of the legal system to the extent the judiciary in their countries is independent. Conversely, whether the legal system favours the accountability of judges for misconduct tends to matter only for those with the most exposure to information through the news media (although support for this finding is not robust to 
model specification). Finally, we saw that there are gaps in trust between individuals based on different levels of education and news media exposure. Under conditions of low independence, the less educated tend to place greater trust in the legal system than those who are more educated, but in contexts of high judicial independence this gap is reversed. The evidence is less clear-cut when the relevant contextual variable is accountability. However, using the multilevel country- and year-fixed effects specification, under conditions of low accountability, those who are more exposed to the news media are less likely to trust the system than those who are least exposed. Under high accountability, that gap disappears.

These findings are broadly consistent with a principal-agent theory of judicial independence and accountability (Garoupa and Ginsburg 20I5). They also have important implications. On the one hand, combining independence and accountability, at least in the dimensions we were able to examine - respectively, collective/institutional and personal/behavioural — seems not only possible but also desirable from the point of view of fostering public confidence in the courts. In other words, agitating the flag of 'threats to judicial independence' whenever measures aimed at improving personal accountability of judges are discussed involves not only an incomplete conceptualization of both concepts but also a potentially lost opportunity to increase public confidence.

However, in no way do our findings suggest that opting for enhancing accountability is more appropriate or more effective in fostering public trust than increasing de facto independence. In fact, it is quite the contrary, given the difference in effect sizes of these 
two institutional properties. To be sure, in several post-authoritarian European systems, judicial independence seems to have been achieved by means of institutions and practices that seem to have created an accountability problem: 'an impregnable force-field that prevents judges from being accountable for the quality and integrity of their judicial work' (Moliterno et al. 20I8). However, we should also keep in mind that in many real world cases of political proposals intending to curb what is often described as 'excessive independence' in order to 'increase judicial accountability' are often ill-disguised 'attempts by political leaders to control the courts (...) couched in accountability terms, while in practice operating as instruments of political control' (Zoll and Wortham 20I8: 878). Our results suggest that increasing the personal accountability of judges at the (unnecessary) expense of the collective independence of courts seems to be a certain path to undermining the public's trust in the system.

The results also suggest new and expanded avenues of inquiry. First, the empirical compatibility between independence and accountability in fostering trust resulted from from a conceptualization and measurement of accountability that focuses on its personal/behavioural dimension. However, other dimensions of accountability, particularly those that are 'collective or institutional' in nature, might not prove so compatible with independence in fostering high levels of trust.

Second, exploring further the interaction between citizens' awareness and the institutional properties of judicial systems is a path for further research that requires overcoming the kind of data limitations we faced. Neither education nor exposure to the news media are 
ideal measures of awareness. In particular, although the results we obtained are compatible with the notion that people who know more about the judicial system are more likely to be sensitive to its properties, they are also compatible, in what concerns the role of education, with the notion that people who care more about independence are more sensitive to that property (Hakhverdian and Mayne 20I2: 739). Measures of both legal awareness and democratic values, which would help us to distinguish between the 'accuracy-inducing' and the 'norm-inducing' roles of education, were unavailable in our surveys. Similarly, although exposure to news media in television does signal an information-seeking behaviour, it is also an imperfect measure of awareness, since the latter also depends on media contents and the way citizens process them.

Finally, important as it may be, 'trust' is not the same as 'legitimacy'. Although strong, effective, and independent judiciaries have often been seen as bulwarks against democratic backsliding (Gibler and Randazzo 20II), it is clear today that, in many countries and contexts - Hungary or Poland today, as before in Argentina, India, Peru, or Venezuela courts themselves have become the primary targets of populist leaders and movements (Arato 2019). To the extent that popular support for judiciaries is one of the ultimate lines of defence against such political attacks (Arato 20I6), understanding such support will require us to go beyond the kind of evaluations of institutional performance represented by 'trust' and to collect and examine measures of deeper institutional loyalty on the part of citizens and their correlates. 


\section{Acknowledgements}

We are grateful to Aylin Aydin-Çakır and Michael J. Nelson for their helpful and stimulating suggestions and to Madison Macy Burns and Constance McKinnon for their research assistance. We also benefited from comments by two anonymous referees and by participants at ICS's SPARC seminar (ICS-ULisbon), at the SAMPOL staff seminar (University of Bergen), and at the MPSA $2019 \mathrm{CwC}$ on Public Support for Comparative Judicial Institutions. The usual disclaimers apply.

\section{Disclosure statement}

No potential conflict of interest was reported by the authors.

\section{Notes on contributors}

Nuno Garoupa is Professor of Law and Associate Dean for Research and Faculty Development, Antonin Scalia Law School, George Mason University. His research interests include law and economics, comparative judicial politics, and empirical legal studies. He has published in numerous leading economics, political science, and law journals. His recent book is Judicial Reputation: A Comparative Study, with Tom Ginsburg (Chicago University Press, 20I5). [ngaroup@gmu.edu; Twitter: @NGaroupa]

Pedro C. Magalhães is a Research Fellow at the Institute of Social Sciences of the University of Lisbon. His research interests include public opinion, elections, and empirical 
legal studies. He has published in numerous leading political science journals. [pedro.magalhaes@ics.ul.pt; Twitter: @PCMagalhaes].

\section{ORCID}

Nuno Garoupa https://orcid.org/0000-000I-6792-09I8

Pedro C. Magalhães https://orcid.org/0000-000I-8934-4552 


\section{References}

Agerberg, M. (2018). 'The Curse of Knowledge? Education, Corruption, and Politics', Political Behavior, 41:2, 369-399.

Ansolabehere, S.D., and A. White (forthcoming). 'Policy, Politics, and Public Attitudes Toward the Supreme Court', American Politics Research. https://doi.org/10.1177/1532673X18765189

Arato, A. (2016). Post Sovereign Constitutional Making: Learning and Legitimacy. Oxford: Oxford University Press.

Arato, A. (2019). 'Populism, Constitutional Courts, and Civil Society', in C. Landfried (ed.), Judicial Power: How Constitutional Courts Affect Political Transformations. Cambridge: Cambridge University Press, 318-41.

Benesh, S. C. (2006). 'Understanding Public Confidence in American Courts', The Journal of Politics, 68:3, 697-707.

Benvenuti, S. (2018). 'The Politics of Judicial Accountability in Italy: Shifting the Balance', European Constitutional Law Review, 14:2, 369-93.

Bermant, G., and R. R. Wheeler (1994) 'Federal Judges and the Judicial Branch: Their Independence and Accountability’, Mercer Law Review, 46:2, 835-61.

Berry, W. D., M. Golder, and D. Milton (2012). 'Improving Tests of Theories Positing Interaction', The Journal of Politics, 74:3, 653-671.

Boateng, Francis D. and Samuel Adjorlolo (2019). 'Judicial Trustworthiness in Africa: Do Macro-Level Conditions Matter?', Crime and Delinquency, 65:12, 1689-710.

Bowal, P., and I. Wanke (2001). 'Lay Knowledge of Courts in Canada', International Journal of the Sociology of Law, 29:2, 173-94.

Burbank, S. B. (1999). 'The Architecture of Judicial Independence', Southern California Law Review, 72, 315-51.

Bühlmann, M., and R. Kunz (2011). 'Confidence in the Judiciary: Comparing the Independence and Legitimacy of Judicial Systems', West European Politics, 34:2, 317-45.

Çakır, A. A., and E. Şekercioğlu (2016). 'Public Confidence in the Judiciary: The Interaction between Political Awareness and Level of Democracy', Democratization, 23:4, 634-56.

Coppedge, M. et al. (2019). Data from: V-Dem Dataset v9. Varieties of Democracy (VDem) Project. Retrieved from: https://doi.org/10.23696/vdemcy19. 
Driscoll, A., and M. Nelson (2018). 'There is No Legitimacy Crisis: Support for Judicial Institutions in Modern Latin America', Sociedad Argentina de Análisis Político, 12:2, 361-77.

European Social Survey Cumulative File, ESS 1-7 (2016). Data from: Data file edition 1.0. NSD. Norwegian Centre for Research Data, Norway - Data Archive and distributor of ESS data for ESS ERIC. Retrieved from https://doi.org/10.21338/NSD-ESS-CUMULATIVE.

Ferejohn, J. A. (2003). 'Independent Judges, Dependent Judiciary: Explaining Judicial Independence', Southern California Law Review, 72, 353-84.

Ferejohn, J. A., and L. Kramer(2002). Independent Judges, Dependent Judiciary: Institutionalizing Judicial Restraint', New York University Law Review, 77, 9621039.

Geyh, C. G. (2014). 'Judicial Independence as an Organizing Principle', Annual Review of Law and Social Science, 10, 185-200.

Garoupa, N., and T. Ginsburg (2009). 'The Comparative Law and Economics of Judicial Councils', Berkeley Journal of International Law, 27:1, 53-83.

Garoupa, N., and T. Ginsburg (2015). Judicial Reputation: A Comparative Theory, Chicago, IL: University of Chicago Press.

Gibler, D. M., and Randazzo, K. A. (2011). 'Testing the effects of independent judiciaries on the likelihood of democratic backsliding', American Journal of Political Science, 55:3, 696-709

Gibson, J. L. (2007). 'The Legitimacy of the US Supreme Court in a Polarized Polity', Journal of Empirical Legal Studies, 4:3, 507-538.

Gibson J. L., and G. A. Caldeira, (2009). 'Knowing the Supreme Court? A Reconsideration of Public Ignorance of the High Court', Journal of Politics, 71:2, 429-41.

Gibson, J. L., G. A. Caldeira, and V. A. Baird (1998). 'On the Legitimacy of National High Courts', American Political Science Review, 92:2, 343-58.

Gibson, J. L., G. A. Caldeira, and L. K. Spence (2003). 'Measuring Attitudes toward the United States Supreme Court', American Journal of Political Science, 47:2, 35467.

Gibson, J. L., M. Lodge, and B. Woodson (2014). 'Losing, but Accepting: Legitimacy, Positivity Theory, and the Symbols of Judicial Authority', Law and Society 
Review, 48:4, 837-66.

Grimes, M. (2006). 'Organizing Consent: The Role of Procedural Fairness in Political Trust and Compliance', European Journal of Political Research, 45:2, 285-315.

Guarnieri, C. (2004). 'Appointment and Career of Judges in Continental Europe: The Rise of Judicial Self-Government', Legal Studies, 24:1-2, 169-87.

Guarnieri, C. (2013). 'Judicial Independence in Europe: Threat or Resource for Democracy?', Representation, 49:3, 347-59.

Hakhverdian, A. and Q. Mayne (2012). 'Institutional Trust, Education, and Corruption: A Micro-Macro Interactive Approach', Journal of Politics, 74:3, 739-50.

Hansen, M. A. (2017). 'Trust in the System? Factors that Impact Citizens' View of Courts in the United Kingdom', Social Science Quarterly, 98:5, 1503-17.

Heisig, J. P., and Schaeffer, M. (2019). 'Why You Should Always Include a Random Slope for the Lower-Level Variable Involved in a Cross-Level Interaction', European Sociological Review, 35:2, 258-79.

Hernández, E. (2016). Data from: MARHIS: Stata Module to Produce Predictive Margins and Marginal Effects Plots with Histogram after Regress, Logit, Xtmixed and Mixed, Statistical Software Components, S458145, Boston College

Department of Economics. Retrieved from http://fmwww.bc.edu/repec/bocode/m/marhis.ado

Hough, M., and J. V. Roberts (1999). 'Sentencing Trends in Britain: Public Knowledge and Public Opinion', Punishment and Society, 1:1, 11-26.

Kennedy, P. (2008). A Guide to Econometrics. Malden, MA: Blackwell.

Kosař, D. (2016). Perils of Judicial Self-Government in Transitional Societies. Cambridge: Cambridge University Press.

La Porta, R., F. Lopez-de-Silanes, and A. Shleifer (2008). 'The Economic Consequences of Legal Origins', Journal of Economic Literature, 46:2, 285-332.

Levinson, S. (2006). 'Identifying “Independence”, Boston University Law Review, 86:5, 1297-308.

Lind, E. A., and T. R. Tyler (1988). The Social Psychology of Procedural Justice. Boston: Springer Science and Business Media.

Linos, K., and K. Twist (2016). 'The Supreme Court, the Media, and Public Opinion: Comparing Experimental and Observational Methods', The Journal of Legal 
Studies, 45:2, 223-254.

Linzer, D. A. and J. K. Staton (2015). 'A Global Measure of Judicial Independence, 1948-2012', Journal of Law and Courts, 3:2, 223-56.

Mirrlees-Black, C. (2013). Improving Public Knowledge about Crime and Punishment', in J. V. Roberts and M. Hough, (eds.), Changing Attitudes to Punishment. London: Willan, 202-15.

Moliterno, J. E., L. Berdisová, P.Čuroš, and J. Mazúr. (2018). ‘Independence Without Accountability: The Harmful Consequences of EU Policy Toward Central and Eastern European Entrants', Fordham International Law Journal, 42, 481.

Mudde, C., and C. R. Kaltwasser, (2017). Populism: A very short introduction. Oxford: Oxford University Press.

North, D. (1990). 'Institutions and Their Consequences for Economic Performance', in C. Ménard and M. M. Shirley (eds,) Handbook of New Institutional Economics. Springer: Dordrecht, 21-30.

Parau, C. E. (2009). 'Beyond Judicial Independence: What Kind of Judiciary is Emerging in Post-Communist Eastern Europe?' Social Foundations of Constitutions Workshop, Wolfson College (Oxford).

Paskov, M., Gërxhani, K., and van de Werfhorst, H. G. (2016). 'Giving up on the Joneses? The relationship between income inequality and status-seeking', European Sociological Review, 33:1, 112-23.

Pemstein, Daniel, Kyle L. Marquardt, Eitan Tzelgov, Yi-ting Wang, and Farhad Miri (2015). 'The V-Dem Measurement Model: Latent Variable Analysis for CrossNational and Cross-Temporal Expert-Coded Data', V-Dem Working Paper No. 21. 4th edition, University of Gothenburg.

Popova, M. (2012). 'Why Doesn't the Bulgarian Judiciary Prosecute Corruption?', Problems of Post-Communism, 59:5, 35-49.

Rabe-Hesketh, S., and A. Skrondal (2012). Multilevel and Longitudinal Modeling Using Stata, Vol II: Categorical Responses, Counts, and Survival. College Station, TX: StataCorp LLC.

Ríos-Figueroa, J., and J. K. Staton (2014). 'An Evaluation of Cross-National Measures of Judicial Independence', Journal of Law, Economics, and Organization 30:1, $104-34$.

Roberts, J. V., and L. J. Stalans (1998). 'Crime, Criminal Justice, and Public Opinion', in M. H. Tonry (ed.), The Handbook of Crime and Punishment. Oxford: Oxford 
University Press, 31-57.

Roussey, L., and B. Deffains (2012). 'Trust in Judicial Institutions: An Empirical Approach', Journal of Institutional Economics, 8:3, 351-69.

Salzman, R., and A. Ramsey (2013). 'Judging the Judiciary: Understanding Public Confidence in Latin American Courts', Latin American Politics and Society, 55, 73-95.

Staton, J., D. Linzer, C. Reenock, and J.Holsinger (2019). Data from: Update, A Global Measure of Judicial Independence, 1900-2015. Retrieved from https://doi.org/10.7910/DVN/NFXWUO, Harvard Dataverse, V1, UNF:6:WO2IMcRMrcGvGhtJZCYs1A==[fileUNF]

Stoutenborough, J. W., and D. P. Haider-Markel (2008). 'Public Confidence in the US Supreme Court: A New Look at the Impact of Court Decisions', Social Science Journal, 45, 28-47.

Van der Meer, T. and A. Hakhverdian (2017). 'Political Trust as the Evaluation of Process and Performance: A Cross-National Study of 42 European countries', Political Studies, 65:1,81-102.

Voigt, S. (2008). 'The Economic Effects of Judicial Accountability: Cross-Country Evidence', European Journal of Law and Economics, 25:2, 95-123.

Voigt, S., and J. Gutmann (2015). 'On the Wrong Side of the Law-Causes and Consequences of a Corrupt Judiciary', International Review of Law and Economics, 43, 156-66.

Walker, L. D. (2016). 'A Multi-Level Explanation of Mass Support for the Judiciary', Justice System Journal, 37:3, 194-210.

Weijters, B., M. Geuens, and N. Schillewaert (2009). 'The Proximity Effect: The Role of Inter-item Distance on Reverse-item Bias', International Journal of Research in Marketing, 26:1, 2-12.

Welzel, C. (2011). 'The Asian Values Thesis Revisited: Evidence from the World Values Surveys’, Japanese Journal of Political Science 12:1, 1-31.

Wenzel, J. P., S. Bowler, and D. J. Lanoue (2003). 'The Sources of Public Confidence in State Courts: Experience and Institutions', American Politics Research, 31:2, 191211.

Zemans, F. K. (1999). The Accountable Judge: Guardian of Judicial Independence, Southern California Law Review, 72, 625-656. 


\section{Zmerli, S. and K. Newton (2008). Social Trust and Attitudes Toward Democracy, Public Opinion Quarterly, 72:4, 706-724.}

\section{Notes}

${ }^{1}$ In Italy, such increased insulation has also led to professional breaches of competence and offenses being, for decades, routinely ignored, while civil liability mechanisms were rendered ineffective by both omission and commission on the part of judges themselves (Benvenuti 2018). Similarly, in Eastern Europe, the dismantling of mechanisms of political control inherited from the Communist regimes led to widely divergent outcomes in terms of ensuring the accountability of judges in countries such as Slovakia, the Czech Republic, Bulgaria, Poland, or Romania (Parau 2009; Popova 20I2; Kosař 20I6).

${ }^{2}$ Nevertheless, for some high courts (Gibson et al. 1998; Gibson and Caldeira 2009), the assumption of widespread public ignorance can also be misguided.

${ }^{3}$ See Online Appendix for information about all variables employed.

${ }^{4} \mathrm{TV}$ exposure, rather than newspaper or radio exposure to news, was the only question of the sort posed in all ESSI-7 surveys.

${ }^{5}$ All these eight measures are based either on expert or official assessments (for most cases) and, in one of them, on business community surveys. For a detailed discussion, see Ríos-Figueroa and Staton (2012) and Linzer and Staton (2015).

${ }^{6}$ We employed the marhis Stata module conceived by Hernández (20I6).

${ }^{7}$ An additional indication is the fact that, in relation to reduced versions of models 8 and 10 (without the interaction term between LJI and JI and News media exposure), we cannot reject the hypothesis that there is no significant difference between models 8 and 10 and those reduced versions (using LR tests). We thank one of the anonymous reviewers for this suggestion. 


\section{Online appendix for Public Trust in the European Legal Systems: Independence, Accountability, and Awareness}

\section{Data for replication and sources}

All data and code files available at Open Science Framework. Link:

https://osf.io/sfj6x/?view only=2If928fea7do434c9fa24fcogo2egb82

a. Individual level data

European Social Survey Cumulative File: Stata file ESSI-7eor.dta.

Available from https://www.europeansocialsurvey.org/downloadwizard/, ESS's cumulative data wizard.

File at OSF: ESSI-7eoI_independence_accountability_awareness.dta (expunged of irrelevant variables).

b. Contextual data.

* Latent Judicial Independence (LJI): from Linzer and Staton (20I5) and Staton, Linzer, Reenock \& Holsinger (20I9). Available at:

https://dataverse.harvard.edu/file.xhtml?persistentId=doi:I0.79Io/DVN/NFXWUO/X5AU $\underline{\text { WX\&version }=\mathrm{I} . \mathrm{O}}$.

*Judicial Accountability (JA): from Coppedge et al. 20I9; Pemstein et al. 20I9. Available at: https://www.v-dem.net/en/data/data-version-8/

* Population (population): population in millions, obtained from https://ec.europa.eu/eurostat/web/population-demography-migrationprojections/data/main-tables.

* GDP per capita (GDPpcc20IIUS): GDP per capita PPP, constant US 20II international dollars, obtained from:

http://api.worldbank.org/.2/en/indicator/NY.GDP.PCAP.PP.KD?downloadformat=excel.

* Common law legal origin (legor_uk): British/common law legal origin, obtained from La Porta et al. (2008), available at:

https://scholar.harvard.edu/files/shleifer/files/data_2.zip. 
2. Required code:

* New_variables_independence_accountabilty_awareness.do: Stata do file that adds all contextual variables, logarithmic transformations for population and GDP per capita, country, country year, year identifiers, and creates new independent and dependent individual level variables with NS/NR as missing and a new individual level variable: Interpersonal trust (interptrust), regression-based factor scores based on ppltrst, pplfair, and pplhlp.

* Analysis_independence_accountability_awareness.do: Stata .do file that produces results for all tables and estimates models 8 and Io without interaction terms and performs LR tests.

All analyses performed with Stata/IC I5.I.

\section{References}

Coppedge, Michael et al. (2019). Data from:V-Dem Dataset v9. Varieties of Democracy (V-Dem) Project. Retrieved from: https://doi.org/10.23696/vdemcy19

European Social Survey Cumulative File, ESS 1-7 (2016). Data from: Data file edition 1.0. NSD. Norwegian Centre for Research Data, Norway - Data Archive and distributor of ESS data for ESS ERIC. Retrieved from https://doi.org/10.21338/NSD-ESS-CUMULATIVE.

La Porta, Rafael, Florencio Lopez-de-Silanes, and Andrei Shleifer (2008). 'The Economic Consequences of Legal Origins', Journal of Economic Literature, 46:2, 285332.

Linzer, Drew A. and Jeffrey K. Staton (2015). 'A Global Measure of Judicial Independence, 1948-2012', Journal of Law and Courts, 3:2, 223-256.

Pemstein, Daniel, Kyle L. Marquardt, Eitan Tzelgov, Yi-ting Wang, and Farhad Miri (2015). 'The V-Dem Measurement Model: Latent Variable Analysis for CrossNational and Cross-Temporal Expert-Coded Data', V-Dem Working Paper No. 21. 4th edition, University of Gothenburg.

Staton, Jeffrey, Drew Linzer, Christopher Reenock, and Jordan Holsinger (2019). Data from: Update, A Global Measure of Judicial Independence, 19002015. Retrieved from https://doi.org/10.7910/DVN/NFXWUO, Harvard Dataverse, V1, UNF:6:WO2IMcRMrcGvGhtJZCYs1A== [fileUNF] 
Table Ar. Individual-level variables employed

\begin{tabular}{|c|c|c|c|c|}
\hline Variable & Observations & Mean & Stddev & $\begin{array}{l}\text { Source: ESS I-7 cumulative file. Available at: } \\
\text { https://www.europeansocialsurvey.org/downloadwizard/. }\end{array}$ \\
\hline $\begin{array}{l}\text { Trust in the } \\
\text { legal system }\end{array}$ & 322,201 & 5.03 & $2.7 \mathrm{I}$ & Original variable: $t r s t l g l$, o-IO. \\
\hline Female & $33 \mathrm{I}, 548$ & .54 & .50 & Original variable: $g n d r$, o Male, I Female. \\
\hline Age & 330,344 & 47.79 & I8.59 & Original variable: $a g e a$, age in years. \\
\hline $\begin{array}{l}\text { Years full- } \\
\text { time education }\end{array}$ & 328,177 & $\mathrm{I} 2 . \mathrm{I} 8$ & 4.09 & $\begin{array}{l}\text { Original variable: eduyrs, years of full time education completed. Top-coded } \\
\text { at } 25 \text {. }\end{array}$ \\
\hline $\begin{array}{l}\text { Interpersonal } \\
\text { trust }\end{array}$ & 326,605 & .00 & .84 & $\begin{array}{l}\text { Regression-based factor scores based on original variables ppltrst, pplfair } \\
\text { and pplhlp ("Most people can be trusted", "Most people try to be fair", } \\
\text { "Most of the time people helpful"), all o-IO }\end{array}$ \\
\hline $\begin{array}{l}\text { Trust in } \\
\text { parliament }\end{array}$ & 317,023 & .00 & .88 & Original variable: trstprl, O-IO \\
\hline $\begin{array}{l}\text { Exposure to } \\
\text { news (TV) }\end{array}$ & 330,535 & I. 89 & I.37 & Original variable: $t v p o l, \mathrm{I}-8$. \\
\hline
\end{tabular}

Table A2. Country-year variables employed

\begin{tabular}{lccc}
\hline Variable & Observations & Mean & Standard deviation \\
\hline Latent Judicial Independence & $\mathrm{I} 73$ & .85 &. $\mathrm{I} 7$ \\
Judicial Accountability & $\mathrm{I} 73$ & $\mathrm{I} .72$ & $\mathrm{I} . \mathrm{I} 3$ \\
GDP per capita (thousands) & $\mathrm{I} 73$ & 34.995 & $\mathrm{I} 3.307$ \\
Common law origin & $\mathrm{I} 73$ & .13 & .34 \\
Population & $\mathrm{I} 73$ & 23.27 & 29.83 \\
\hline
\end{tabular}

